\title{
Ultraviolet radiation induces reversal of the bioavailability of DOM to marine bacterioplankton
}

\author{
Ingrid Obernosterer ${ }^{1}$, Richard Sempéré ${ }^{2}$, Gerhard J. Herndl ${ }^{1, *}$ \\ ${ }^{1}$ Department of Biological Oceanography, Netherlands Institute for Sea Research (NIOZ), PO Box 59, 1790 AB Den Burg, \\ Texel, The Netherlands \\ ${ }^{2}$ Laboratoire de Microbiologie Marine (LMM), CNRS UPR 223, Case 907, Campus de Luminy, 13288 Marseille Cedex 9, France
}

\begin{abstract}
The effect of solar radiation on the bioavailability of dissolved organic matter (DOM) was investigated during a cruise in the Southern Ocean $\left(\sim 44.5^{\circ} \mathrm{S}, 63^{\circ} \mathrm{E}\right)$ in January and February 1999. Seawater was collected in the chlorophyll maximum layer (CML, 30 to $80 \mathrm{~m}$ depth) and in deep waters (DW, 200 to $5000 \mathrm{~m}$ depth), filtered through $0.2 \mu \mathrm{m}$ pore-size filters, and exposed to surface solar irradiation for $8 \mathrm{~h}$. The bioavailability of the irradiated DOM and of that in the corresponding dark treatment was subsequently tested in bioassay experiments performed in the dark. Seawater from the CML was also size-fractionated and the effect of solar radiation on the bioavailability of the $<20 \mathrm{kDa}$ DOM fraction was compared with that of the bulk DOM. Our results clearly demonstrate that the biological reactivity of DOM from both the CML and DW following exposure to solar radiation is inversely related to the initial bioavailability of the DOM prior to its exposure. The photochemically induced stimulation of the bacterial activity was $\sim 2$-fold higher in the $<20 \mathrm{kDa}$ fraction than in the bulk DOM. These results clearly indicate that initially bioreactive DOM can be rendered biologically more recalcitrant by exposure to solar radiation, while DOM of initially low bioavailability can be, at least partly, photochemically transformed to compounds of higher biological reactivity.
\end{abstract}

KEY WORDS: Dissolved organic matter · Ultraviolet radiation · DOM-photoreactivity · Bacterioplankton $\cdot$ Southern Ocean

\section{INTRODUCTION}

Photochemical transformation of dissolved organic matter (DOM) can considerably affect its biological availability to bacterioplankton. The photochemical alteration of DOM and the subsequently released low molecular weight organic and inorganic compounds have been recognized as a potentially important substrate for bacterioplankton (see review by Moran \& Zepp 1997). In contrast, recent evidence indicates that the biovailability of irradiation-exposed DOM can also be reduced compared to non-exposed DOM (Benner \& Biddanda 1998, Tranvik \& Kokalj 1998, Obernosterer et al. 1999b). Loss of organic carbon due to the photochemical production of inorganic carbon species (Salo-

*Corresponding author. E-mail: herndl@nioz.nl nen \& Vähätalo 1994, Miller \& Zepp 1995, Graneli et al. 1996), the photochemical production of reactive oxygen species such as hydrogen peroxide (Cooper et al. 1988), and photochemical transformation of DOM resulting in compounds that are biologically more recalcitrant might be responsible for the observed reduction in bacterial activity on irradiated DOM.

There are indications that the response of bacterioplankton to photochemically induced changes of DOM is related to the original biological availability of the DOM prior to exposure to solar radiation (Benner \& Biddanda 1998, Obernosterer et al. 1999b). The bulk DOM can roughly be separated into 3 pools: a highly labile pool with turnover times of hours to days, a semilabile pool with turnover times on a seasonal time scale, and a refractory DOM pool with a turnover of $>1$ yr (Kirchman et al. 1993). Only 25 to $50 \%$ of the bulk DOM pool has been characterized on a molecular 
level so far, indicating that carbohydrates and amino acids account for an important part of the labile DOM (Suttle et al. 1991, Benner et al. 1992, Rich et al. 1996). Size fractionations of DOM have shown that low molecular weight DOM $(<1000 \mathrm{Da})$, comprising $\sim 70$ to $80 \%$ of the bulk oceanic DOM (Carlson et al. 1985b, Benner et al. 1992, Guo et al. 1995), is mainly comprised of highly degraded material with low biological reactivity (Tranvik 1990, Amon \& Benner 1994). The relative contribution of biologically recalcitrant DOM increases from surface to deep waters (Carlson \& Ducklow 1995). However, this refractory DOM pool contains highly light-absorbing moities, rendering it photochemically reactive (Kieber et al. 1989, Mopper et al. 1991).

The Antarctic Circumpolar Current is a unique global link connecting all major oceans. Most of the waters transported in the circumpolar current represent a mixture of waters formed in other parts of the world's oceans (Whitworth \& Worth 1987, Orsi et al. 1995). Deep waters originating further north, such as the North Atlantic Deep Water Current, enter the subpolar regime and mix with Antarctic shelf waters (Orsi et al. 1995). The transport of deep waters into the surface mixed layer of specific regions of the Southern Ocean could lead to large-scale photochemically induced transformation of DOM, thereby significantly influencing bacterial activity.

In this study, we tested the hypothesis that photochemically induced changes of the biological reactivity of DOM are directly related to the initial bioavailability of the DOM prior to exposure to solar irradiation. Experiments were performed with DOM originating from different water masses and depth layers during a cruise in the Southern Ocean. We further compared the biological and photochemical reactivity of the $<20 \mathrm{kDa}$ DOM fraction with that of the bulk DOM pool, and used bovine serum albumin (BSA) as a biologically labile model compound to elucidate the relationship between the biological and the photochemical reactivity of different components of the DOM pool.

\section{MATERIALS AND METHODS}

Sampling sites. The study was carried out during the ANTARES IV cruise on board the RV 'Marion Dufresne II' in January and February 1999 in the Indian sector of the Southern Ocean. The main survey area, the central Crozet Basin $\left(\sim 44.5^{\circ} \mathrm{S}, 63^{\circ} \mathrm{E}\right)$, is characterized by multiple fronts where the Agulhas Return Current and the Antarctic Circumpolar Current (ACC) converge. The ACC in this sector of the Southern Ocean mainly consists of the Subantarctic and the Subtropical Front
(Park et al. 1993). Samples were collected at 3 main stations, the Polar Frontal Zone south of the Subantarctic Front (Stn 3), the Subtropical Zone north of the Subtropical Front (Stn 7) and the Subtropical Zone north of the Agulhas Return Current (Stn 8, see Table 1). Samples were also collected across a transect between the Subantarctic Front and the Agulhas Return Current (Stns P3, P4, P5, G1, G2, G3: see Table 1). Generally, concentrations of inorganic nitrogen in surface waters varied between 0.1 and $17.9 \mu \mathrm{M}$, and in waters $\geq 200 \mathrm{~m}$ depth between 11.2 and $33 \mu \mathrm{M}$ (courtesy S. Blain). Inorganic phosphate concentrations in this area have been reported to range between 0.3 and $1.1 \mu \mathrm{M}$ in surface waters and between 0.5 and $2.4 \mu \mathrm{M}$ at depths $\geq 200 \mathrm{~m}$ (Treguer et al. 1980). Chlorophyll a concentrations ranged between 0.13 and $0.87 \mathrm{gg} \mathrm{l}^{-1}$ in surface waters (see Table 1).

Experimental design. Seawater samples were collected from the chlorophyll maximum layer (CML, 30 to $80 \mathrm{~m}$ depth) and from deep-water layers (DW, 200 to $5000 \mathrm{~m}$ depth) using $10 \mathrm{l}$ Niskin bottles mounted on a CTD rosette. In order to determine the initial DOM bioavailability, raw seawater was subsampled $(20 \mathrm{ml}$ for CML, $40 \mathrm{ml}$ for DW) for measurements of bacterial production as described below. For the determination of irradiation-induced changes of the DOM bioavailability, one fraction of the freshly collected seawater was immediately filtered through $0.2 \mu \mathrm{m}$ polycarbonate filters (Nuclepore, $47 \mathrm{~mm}$ filter diameter) to obtain particle-free seawater, and the other fraction was filtered through $0.8 \mu \mathrm{m}$ filters (Nuclepore, $47 \mathrm{~mm}$ filter diameter) to prepare the bacterioplankton inocula. The filters were pre-rinsed with 11 Milli-Q water and $500 \mathrm{ml}$ seawater before use. All glassware used was rinsed with $0.1 \mathrm{~N} \mathrm{HCl}$ and subsequently with Milli-Q water. Exposure of the $0.2 \mu \mathrm{m}$ filtrate from the different depth layers to surface solar irradiation was performed in quartz glass tubes (250 ml volume) sealed at both ends with Teflon foil (200 $\mu \mathrm{m}$ thick, Fluorplast, Amsterdam, The Netherlands). The Teflon foil was supported by PVC holders fitted to the tube with an O-ring. Respective dark controls were wrapped in aluminum foil. The quartz tubes were incubated in a water bath on the deck of the ship connected to a running seawater system to maintain in situ temperature conditions of the surface layers $\left(10\right.$ to $\left.17^{\circ} \mathrm{C}\right)$. All incubations were done from 09:00 to 18:00 h. To determine the biological reactivity of the DOM, the irradiated and the respective dark treatments (180 ml each) were inoculated with a natural bacterial assemblage (0.8 $\mu \mathrm{m}$-filtered seawater; $20 \mathrm{ml})$ collected at the corresponding depths (CML and DW). The dilution cultures were kept in the dark at surface water temperature for $24 \mathrm{~h}$ before subsamples for bacterial production were taken. 
In additional sets of experiments (see Table 1), the photoreactivity of the $<20 \mathrm{kDa}$ DOM fraction and photo-induced changes in the bioavailability of an originally labile compound were determined. In order to determine the photoreactivity of the DOM fraction $<20 \mathrm{kDa}$, the $0.2 \mu \mathrm{m}$ filtrate from the CML was passed through a combusted $\left(450^{\circ} \mathrm{C}\right.$ for $\left.4 \mathrm{~h}\right)$ and prerinsed (1 1 Milli-Q water) $0.02 \mu \mathrm{m}$ aluminum oxide filter (Anopore, $47 \mathrm{~mm}$ filter diameter). The photo-induced changes in the bioavailability of an originally labile compound were followed by amending the $0.2 \mu \mathrm{m}$ filtrate of the different depth layers with the protein bovine serum albumin (BSA; final conc. $416 \mu \mathrm{M} \mathrm{C}$ ) prior to irradiation. Exposure to surface solar irradiation and the subsequent preparation of the bacterial batch cultures of both, the $<20 \mathrm{kDa}$ DOM fraction and the BSA-amended treatments followed the protocol described above. Ten ml samples for DOC analyses were taken from the $0.2 \mu \mathrm{m}$ and the $0.02 \mu \mathrm{m}$ filtrate, fixed with $50 \mu \mathrm{lgCl}_{2}$ (10 $\mathrm{mg} \mathrm{l}^{-1}$ final conc.), and kept in sealed pre-combusted ampoules until analysis. DOM fluorescence was measured on the $0.2 \mu \mathrm{m}$ and the $0.02 \mu \mathrm{m}$ filtrates immediately after filtration and after exposure to solar irradiation and in the respective dark treatments, as described below.

Bacterial production measurements. Bacterial production was measured by $\left[{ }^{3} \mathrm{H}\right]$ leucine (specific activity: $136 \mathrm{Ci} \mathrm{mmol}^{-1}$; Amersham, UK) incorporation. Bacterial production on raw seawater samples was measured in $20 \mathrm{ml}$ samples from the CML (final conc. $10 \mathrm{nM}$ ) and in $40 \mathrm{ml}$ samples from the DW (final conc. $5 \mathrm{nM}$ ). Twenty $\mathrm{ml}$ were used to measure bacterial production (final conc. $10 \mathrm{nM}$ ) in the dilution cultures. Incubations were done in triplicate with 1 blank at in situ temperature in the dark; blanks were fixed with formaldehyde (final conc. $4 \%$, v/v) 10 min before adding the tracer. Incubation times for raw seawater samples were $1 \mathrm{~h}$ for samples originating from the CML and $200 \mathrm{~m}$ depth, $3 \mathrm{~h}$ for samples from $500 \mathrm{~m}$ depth, and $10 \mathrm{~h}$ for samples from $\geq 1000 \mathrm{~m}$ depth. All samples from the dilution cultures were incubated for $1 \mathrm{~h}$. Following incubation, the samples were filtered through $0.2 \mu \mathrm{m}$ cellulose nitrate filters (Millipore GSWP, $25 \mathrm{~mm}$ diameter filter) and rinsed twice with $10 \mathrm{ml}$ ice-cold $5 \%$ trichloroacetic acid (Prolabo RP Normapur) for $5 \mathrm{~min}$. The filters were dissolved in $1 \mathrm{ml}$ ethylacetate, and after $10 \mathrm{~min} 8 \mathrm{ml}$ of scintillation cocktail (PCS Amersham) was added. The radioactivity incorporated into bacterial cells was counted in a Canberra Packard Tricarb 2000, and the disintegrations per minute were converted to the actual amount of substrate incorporated.

DOC analysis. DOC measurements were performed on a Shimadzu TOC-5000A with a quartz combustion column filled with $1.2 \%$ Pt on silica pillows with an approximate diameter of $2 \mathrm{~mm}$ (Cauwet 1994). Modifications of the unit have been described in Yoro et al. (1997). DOC samples were acidified with $10 \mu \mathrm{l}$ of $85 \%$ $\mathrm{H}_{3} \mathrm{PO}_{4}$ to a $\mathrm{pH}$ of $\sim 2$, and sparged with $\mathrm{CO}_{2}$-free air for $10 \mathrm{~min}$ to remove inorganic carbon. One hundred $\mu \mathrm{l}$ of sample were subsequently injected in triplicate, and the analytical precision was on average $\sim 3 \%$. Standards were prepared with potassium hydrogen biphthalate (Kanto Chemical Co Inc. Kyoto, Japan).

DOM fluorescence. Fluorescence of the DOM was measured at an excitation wavelength of $350 \mathrm{~nm}$ and an emission wavelength of $450 \mathrm{~nm}$ on a Perkin Elmer MPF-66 fluorescence spectrophotometer using a $1 \mathrm{~cm}$ quartz cuvette. DOM fluorescence is expressed as quinine sulfate units $(1 \mathrm{QSU}=1 \mathrm{ppb}$ quinine sulfate in $0.05 \mathrm{M} \mathrm{H}_{2} \mathrm{SO}_{4}$ ).

Statistical analysis. Differences among treatments were tested by analysis of variance (2-way ANOVA) and by the Tukey-test for pairwise comparison. The Wilcoxon test for matched-pairs was used to check for treatment effects (irradiation vs dark) on variables in the BSA-addition experiments. Statistics were performed with SYSTAT 5.2 (Wilkinson 1990).

\section{RESULTS}

\section{Bacterial response to DOM of different origin exposed to solar radiation}

Initial bacterial activity in the raw seawater samples were $\sim 1$ to 2 orders of magnitude higher in the CML than in the water layers from 200 to $5000 \mathrm{~m}$ depth. In contrast, DOC concentrations varied only by a factor of up to 2 between the mixed surface layer and $5000 \mathrm{~m}$ depth (Table 1). This resulted in DOC-normalized leucine incorporation ranging from 0.16 to $1.23 \mathrm{pmol}$ leu $\mathrm{h}^{-1}(\mu \mathrm{mol} \mathrm{DOC})^{-1}$ in the CML and from 0.0014 to 0.0276 pmol leu $\mathrm{h}^{-1}$ ( $\left.\mu \mathrm{mol} \mathrm{DOC}\right)^{-1}$ in DW, clearly indicating the substantially lower bioavailability of the DOM originating from $\geq 200 \mathrm{~m}$ depth. DOC-normalized fluorescence of the DOM was significantly higher (by $\sim 40 \%$ ) in samples from DW than in samples from the CML (ANOVA, $\mathrm{p}=0.008, \mathrm{n}=8$; Table 1). Diel integrated surface solar UVB radiation on the days when the experiments were performed varied between 2.3 and $5.2 \mathrm{~kJ} \mathrm{~m}^{-2}$ (NASA, Goddard Space Flight Center, New York). Exposure of the DOM from the different water layers to surface solar irradiation resulted in variable changes in the DOM bioavailability to bacterioplankton (Fig. 1). The ratio of the bacterial activity in the irradiation-exposed/dark treatment (I/D ratio) was inversely related to the initial DOC-normalized bacterial activity for the DOM from the CML as well as from the DW. In the CML, I/D ratios ranged 
Table 1. Stations sampled during ANTARES IV cruise with corresponding sampling depth, concentration of DOC, DOM fluorescence (as quinine sulfate units, QSU) prior to exposure to solar irradiation, and chlorophyll a concentration. nd: not determined. Superscripted numbers for Stns 7 and 8 indicate individual experiments performed at one station

\begin{tabular}{|c|c|c|c|c|c|c|}
\hline Stn & $\begin{array}{l}\text { Latitude } \\
\qquad\left({ }^{\circ} \mathrm{S}\right)\end{array}$ & $\begin{array}{l}\text { Longitude } \\
\quad\left({ }^{\circ} \mathrm{E}\right)\end{array}$ & $\begin{array}{l}\text { Depth } \\
\text { (m) }\end{array}$ & $\begin{array}{l}\text { DOC } \\
(\mu \mathrm{M})\end{array}$ & $\begin{array}{c}\text { DOM- } \\
\text { fluorescence } \\
\left(\mathrm{QSU}, \mu \mathrm{M}^{-1} \mathrm{DOC}\right)\end{array}$ & $\begin{array}{c}\text { Chl } a \\
\left(\mu g l^{-1}\right)\end{array}$ \\
\hline \multicolumn{7}{|c|}{ Chlorophyll maximum layer } \\
\hline $3^{a}$ & $46^{\circ} 01.74^{\prime}$ & $62^{\circ} 45.66^{\prime}$ & 30 & 70 & 0.0039 & 0.27 \\
\hline $\mathrm{P} 5^{\mathrm{a}}$ & $43^{\circ} 49.76^{\prime}$ & $64^{\circ} 30.01^{\prime}$ & 60 & 67 & 0.0074 & 0.13 \\
\hline G1 & $45^{\circ} 11.54^{\prime}$ & $63^{\circ} 04.65^{\prime}$ & 80 & 64 & 0.0063 & 0.27 \\
\hline G2 & $44^{\circ} 50.18^{\prime}$ & $62^{\circ} 52.67^{\prime}$ & 35 & 80 & 0.0050 & 0.67 \\
\hline $\mathrm{P}^{\mathrm{a}}$ & $44^{\circ} 37.92^{\prime}$ & $62^{\circ} 49.37^{\prime}$ & 50 & 64 & nd & 0.55 \\
\hline G3 & $44^{\circ} 28.85^{\prime}$ & $62^{\circ} 43.99^{\prime}$ & 45 & 65 & 0.0069 & 0.24 \\
\hline $\mathrm{P} 4^{\mathrm{b}}$ & $45^{\circ} 19.95^{\prime}$ & $61^{\circ} 52.63^{\prime}$ & 40 & 63 & 0.0059 & 0.87 \\
\hline $7^{1, a b}$ & $44^{\circ} 11.48^{\prime}$ & $63^{\circ} 24.44^{\prime}$ & 30 & 65 & 0.0075 & 0.73 \\
\hline $7^{3, a b}$ & $43^{\circ} 56.13^{\prime}$ & $64^{\circ} 47.97^{\prime}$ & 40 & 73 & 0.0071 & 0.79 \\
\hline $8^{1, b}$ & $43^{\circ} 00.94^{\prime}$ & $62^{\circ} 55.96^{\prime}$ & 50 & 73 & 0.0087 & 0.41 \\
\hline $8^{2}$ & $42^{\circ} 54.80^{\prime}$ & $63^{\circ} 04.10^{\prime}$ & 30 & 73 & 0.0083 & 0.34 \\
\hline \multicolumn{7}{|c|}{ Deep water } \\
\hline $3^{a}$ & $46^{\circ} 01.74^{\prime}$ & $62^{\circ} 45.66^{\prime}$ & 200 & 60 & 0.0047 & 0.01 \\
\hline $\mathrm{P}^{\mathrm{a}}$ & $43^{\circ} 49.76^{\prime}$ & $64^{\circ} 30.01^{\prime}$ & 500 & 52 & 0.0061 & $<0.01$ \\
\hline G2 & $44^{\circ} 50.18^{\prime}$ & $62^{\circ} 52.67^{\prime}$ & 1000 & 49 & 0.0119 & $<0.01$ \\
\hline $7^{1, \text { a }}$ & $44^{\circ} 11.48^{\prime}$ & $63^{\circ} 24.44^{\prime}$ & 1000 & 47 & 0.0110 & $<0.01$ \\
\hline $7^{2}$ & $44^{\circ} 00.12^{\prime}$ & $64^{\circ} 09.91^{\prime}$ & 200 & 67 & 0.0079 & 0.01 \\
\hline $7^{3}$ & $43^{\circ} 56.13^{\prime}$ & $64^{\circ} 47.97^{\prime}$ & 200 & 58 & 0.0106 & 0.01 \\
\hline $8^{1}$ & $43^{\circ} 06.81^{\prime}$ & $62^{\circ} 29.63^{\prime}$ & 3000 & 50 & 0.0169 & $<0.01$ \\
\hline $8^{2}$ & $43^{\circ} 00.94^{\prime}$ & $62^{\circ} 55.96^{\prime}$ & 5000 & 47 & 0.0149 & $<0.01$ \\
\hline
\end{tabular}

from 0.48 to 6.82 and were therefore similar to I/D ratios from DW (0.70 to 10.52). In DW, the highest I/D ratios were detectable for samples from $\geq 500 \mathrm{~m}$ depth (Fig. 1).

\section{Photochemical reactivity of $<20$ kDa DOM fraction}

The $<20 \mathrm{kDa}$ DOM fraction accounted for $\sim 94 \pm 5 \% \quad(\mathrm{n}=4$, range 86 to $98 \%$ ) of the bulk DOM (measured as DOC). However, bacterial activity in the treatments kept in the dark was significantly lower (15 to 83\%; ANOVA, $\mathrm{p}=0.034, \mathrm{n}=4)$ in the $<20 \mathrm{kDa}$ DOM fraction than in the bulk DOM. Carbonnormalized bacterial activity in the $<20 \mathrm{kDa}$ DOM fraction was, on average, lower by a factor of 2 ( $\mathrm{n}=4$, range 1.2 to 5.7 ) than bulk DOM. The response of bacterial activity to exposure of the $<20 \mathrm{kDa}$ DOM fraction to surface solar irradiation exhibited a trend similar to that obtained for the corresponding bulk DOM (Fig. 2). However, the stimulation of bacterial activity by photochemically induced transformation of the DOM pool was 2 -fold higher for the $<20 \mathrm{kDa}$ DOM fraction than for the bulk DOM (Fig. 2).

\section{Response of the bacterial activity to BSA-amended, irradiated DOM}

The addition of BSA to DOM originating from the CML and subsequent exposure to surface solar irradiation resulted in a significant increase in bacterial activity compared to the corresponding dark control (mean I/D ratio $=2 \pm 0.65$; Wilcoxon, $\mathrm{p}=0.022$, $\mathrm{n}=5$; Fig. 3). Exposure of the corresponding unamended DOM resulted in a mean I/D ratio of $1.5 \pm 0.72$; however, no significant difference was detectable between the irradiated and the dark treatments. A contrasting pattern was observed for DOM originating from DW. While unamended, irradiated DW showed significantly higher bacterial activity in the solar irradiation-exposed DOM (mean I/D ratio $=2.2 \pm 0.73 ;$ Wilcoxon, $\mathrm{p}=0.05$, $\mathrm{n}=3$ ); BSA-amended, irradiated DOM from DW resulted in a decrease in bacterial activity compared to the corresponding dark control (mean $\mathrm{I} / \mathrm{D}$ ratio $=$ $0.35 \pm 0.06$; Wilcoxon, $\mathrm{p}=0.05, \mathrm{n}=3$; Fig. 3)

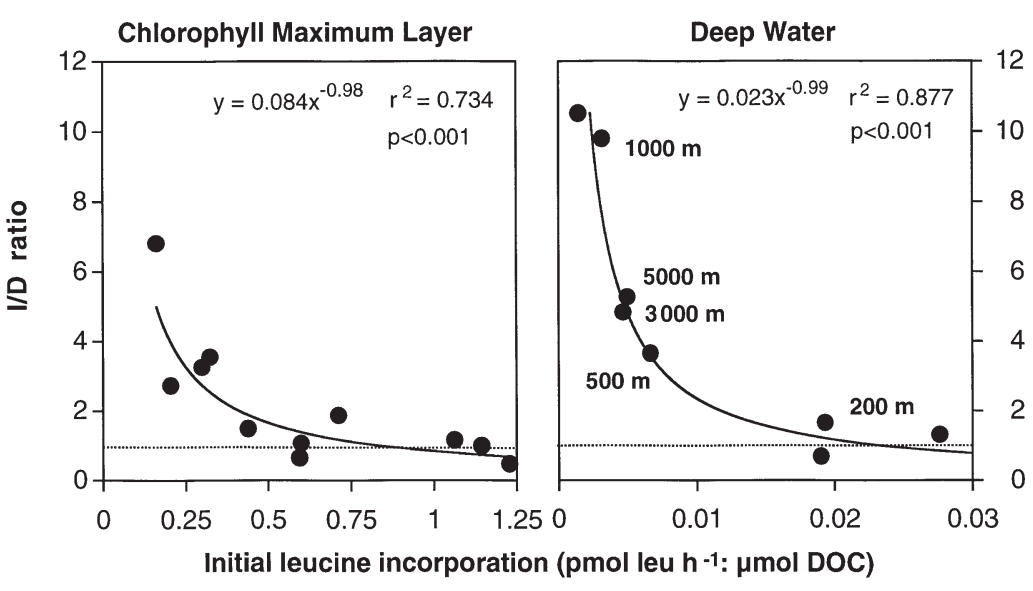

Fig. 1. Relationship between initial DOC-normalized bacterial activity of DOM originating from the chlorophyll maximum layer and deep waters and I/D ratio (ratio between bacterial activity in the irradiation-exposed sample and corresponding dark control). Dotted line indicates I/D ratio of 1 


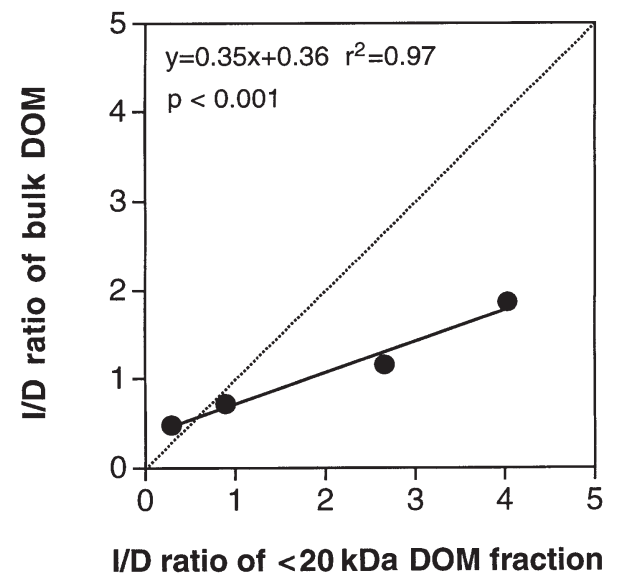

Fig. 2. Relationship between I/D ratio of the $<20 \mathrm{kDa}$ fraction and I/D ratio of the bulk DOM of samples collected in the chlorophyll maximum layer. Dotted line indicates 1:1 relationship

\section{DOM fluorescence}

Initial DOC-normalized fluorescence was significantly higher for DOM originating from DW than for DOM from the CML (ANOVA, $\mathrm{p}=0.008, \mathrm{n}=8$; Table 1 ). No significant difference in the initial fluorescence of the bulk DOM and the $<20 \mathrm{kDa}$ DOM fraction was detectable. A significant decrease in DOM fluorescence during exposure to surface solar irradiation for $8 \mathrm{~h}$ was observed for DOM from the CML (by $~ 5 \%$ ) and DW (by $\sim 10 \%$; Table 2). The loss of fluorescence was, on average, 2-fold higher in irradiation-exposed DOM from DW than from the CML. No decrease in DOM fluorescence, however, was observed in the $<20 \mathrm{kDa}$ DOM

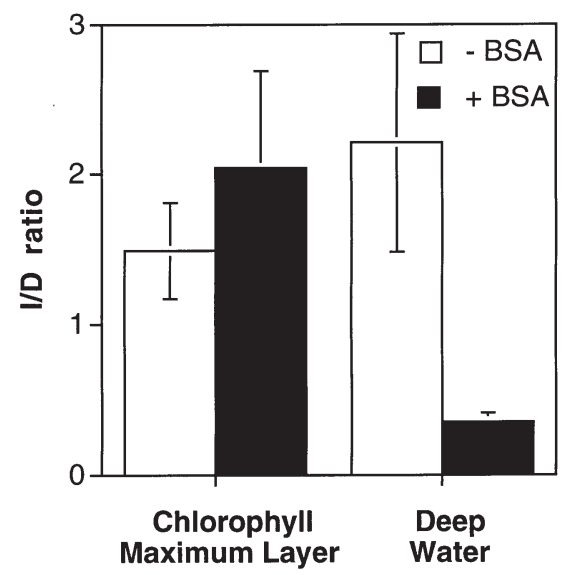

Fig. 3. Ratio (means $\pm \mathrm{SE}$ ) between bacterial activity in the irradiation-exposed sample and corresponding dark control (I/D ratio) of DOM originating from the chlorophyll maximum layer and the deep-water layers and of the corresponding bovine serum albumin (BSA)-amended treatments; $416 \mu \mathrm{M} \mathrm{C}$ (final conc.) were added fraction during exposure to solar irradiation. Also, BSAamended samples originating from the CML and DW exposed to surface solar irradiation did not show an alteration in the DOM fluorescence compared to the corresponding dark incubations (Table 2).

\section{DISCUSSION}

In the present study, the effect of surface solar irradiation on the bioavailability of DOM originating from both the CML and the DW was inversely related to the initial DOM bioavailability. These results confirm recent findings on the relationship between the bioavailability and photochemically induced changes of DOM from the Mediterranean Sea (Obernosterer et al. 1999b), and indicate therefore that this relationship is a common phenomenon of oceanic DOM. These solar irradiation-induced alterations can be assessed by comparing the bacterial activity in the irradiationexposed/dark treatment (I/D ratio). In the Mediterranean Sea, I/D ratios were similar to those in the present study. However, a pronounced difference in the I/D ratios of DOM from the CML, being consistently $<1$, and mesopelagic waters, being $>1$, was observed in the Mediterranean Sea (Obernosterer et al. 1999b).

\section{Photoreactivity of DOM from CML and from DW}

Exposure of DOM from the CML to surface solar irradition resulted in either stimulated or reduced bacterial activity following exposure compared to the treatments in the dark (Fig. 1). In contrast, irradiated DOM from

Table 2. DOM fluorescence (means $\pm \mathrm{SD}$ ) of water originating from chlorophyll maximum layer and from deep water after exposure to surface solar irradiation for $8 \mathrm{~h}$, as percentage of fluorescence measured in corresponding samples in the dark. +BSA: $416 \mu \mathrm{M}$ C (final conc.) bovine serum albumin added; $\mathrm{n}$ : number of experiments. No significant differences between initial DOM fluorescence and corresponding samples in the dark were detected. ${ }^{*}$ Significant difference between irradiated sample and corresponding dark control (ANOVA, $\mathrm{p}<0.05$ )

\begin{tabular}{|ccc|}
\hline $\begin{array}{c}\text { Chlorophyll maximum layer } \\
\text { Bulk DOM }\end{array}$ & $\begin{array}{c}\text { Deep water } \\
\text { bulk DOM }\end{array}$ \\
\hline $95^{*}$ & 99 & $90^{*}$ \\
\pm 14 & \pm 13 & \pm 13 \\
$(\mathrm{n}=10)$ & $(\mathrm{n}=4)$ & $(\mathrm{n}=8)$ \\
$+\mathrm{BSA}$ & & 97 \\
112 & & \pm 10 \\
\pm 19 & $(\mathrm{n}=4)$ \\
$(\mathrm{n}=4)$ & \\
\hline
\end{tabular}


DW stimulated subsequent bacterial growth, albeit at highly variable rates (Fig. 1). Photochemically induced stimulation of the bacterial activity (i.e. I/D ratios $>1$; Fig. 1) followed the same trend for DOM originating from the CML and the DW, resulting in similar I/D ratios. Based on the photochemical production of low molecular weight carbonyl compounds and carbon monoxide, it has been concluded that deep-water DOM is $\sim 5$ to 10 times more photoreactive than DOM of surface waters (Mopper et al. 1991). In the present study, the loss in fluorescence which has been shown to be related to the photochemical degradation of DOM (Kieber et al. 1990, Graneli et al. 1996) was about 2-fold higher in DW-DOM than in DOM from the CML (Table 2). The increased bacterial activity on irradiation-exposed DOM compared to DOM in the dark can be attributed to the release of organic and/or inorganic nutrients from refractory moities. The importance of these photoproducts in stimulating bacterial activity probably depends on the substrate or element limiting bacterioplankton growth. DW-DOM is dominated by biologically recalcitrant matter; however, deep waters are usually replete in inorganic nutrients. In contrast, DOM present in surface waters is characterized by a higher degree of bioreactivity, while inorganic nutrient sources frequently limit growth, at least during daytime when competition with phytoplankton for inorganic nutrients is intense (Thingstad \& Rassoulzadegan 1995, Rivkin \& Anderson 1997, Kuipers et al. 2000). In a recent study, Skoog et al. (1999) report that bacterial growth is limited by the availability of inorganic nutrients in the CML, while above and below the CML bacterial growth is limited by organic carbon. These authors suggest a depth-dependent alteration in factors limiting bacterial growth.

Thus, the photochemical production of initially limiting nutrient sources will significantly determine the overall effect of irradiation on the bioavailability of the DOM. Assuming that bacterioplankton growth on DOM originating from the CML is limited in nitrogen or phosphorus rather than in carbon (Skoog et al. 1999, Kuipers et al. 2000), the photochemically induced release of labile nitrogen or phosphorus species will enhance bacterial activity. If a C:N:P ratio of 45:9:1 is assumed for bacterioplankton (Goldman et al. 1987), nitrogen- or phosphorus-limited bacterial growth can be significantly stimulated by a comparatively low increase in the concentration of these nutrients, while relatively more carbon is needed for bacterial growth. Thus, even at several-fold lower photoproduction rates of surface water DOM, compared to DOM from deep waters (Mopper et al. 1991), exposure of surface-water DOM to solar irradiation could result in an enhancement of subsequent bacterial growth similar to that observed in the present study. This also implies that the photochemical production of biologically available substrates may not necessarily lead to a stimulation of bacterial activity following exposure of DOM to solar irradiation. Several studies quantifying the microbial uptake of specific photochemically produced substances support this notion. These studies have shown that the photochemical production of bioavailable carbon compounds exceeds their bacterial utilization ( 3- to 30-fold) (Kieber et al. 1989, Bertilsson \& Tranvik 1998, Obernosterer et al. 1999a).

\section{Reduced bacterial activity on DOM exposed to surface solar irradiation}

The decreased bacterial activity on irradiated DOM compared to the dark control observed in the present study (Fig. 1) has also been reported in other studies (Benner \& Biddanda 1998, Tranvik \& Kokalj 1998, Obernosterer et al. 1999b). Polymerization reactions and humification (Harvey et al. 1983), which can also be photochemically induced (Kieber et al. 1997), have been shown to render parts of the DOM biologically less labile (Carlson et al. 1985a, Keil \& Kirchman 1994).

Loss of DOC due to the photochemical production of carbon gases has also been suggested to account for the decreased bacterial activity on irradiation-exposed DOM compared to dark controls (Gobler et al. 1997). However, in recent studies of Tranvik \& Kokalj (1998) and Pausz \& Herndl (1999) using algal-derived DOC, the loss of DOC due to photo-oxidation decreased the DOC concentration by less than $1 \%$ during an exposure period of $\leq 16 \mathrm{~h}$, while microbial activity was inhibited by 15 to $20 \%$. Also, in humic lakes, photochemical production of inorganic carbon has been shown to account for only up to a $\sim 4 \%$ decrease in the initial DOC concentration (Graneli et al. 1996, Reitner et al. 1997). Thus, the effect of photochemical carbon gas production on bacterioplankton activity was probably insignificant in our study as well. The photochemical production of toxic substances, such as hydroxyl radicals, might also lead to reduced bacterial activity on irradiation-exposed DOM (Lund \& Hongve 1993, Anesio et al. 1999). However, to our knowledge, no direct evidence of photo-induced formation of toxic substances and their effect on bacterioplankton activity has been presented for marine systems thus far.

\section{Photoreactivity of DOM of different molecular weight and biological reactivity}

In the present study, photo-induced stimulation of the bacterioplankton activity was twice as high in the $<20 \mathrm{kDa}$ DOM fraction than in the bulk 
DOM (Fig. 2). As indicated by the 2 -fold lower DOCnormalized bacterial activity in the $<20 \mathrm{kDa}$ DOM fraction compared to the bulk DOM of the samples in the dark, the $<20 \mathrm{kDa}$ DOM fraction is composed of biologically refractory material. According to the relationship established in the present study (Fig. 1), the effect of solar radiation on the bioavailability of the DOM might therefore be more pronouced for the $<20 \mathrm{kDa}$ DOM fraction than for the bulk DOM. We further suggest that compounds present in the $>20 \mathrm{kDa}$ DOM fraction might counteract the pronounced photochemically-induced stimulation of the bacterial activity observed in the $<20 \mathrm{kDa}$ DOM fraction. The model protein BSA used in this study has a molecular weight of $\sim 60 \mathrm{kDa}$ and is highly labile. Addition of BSA to DOM from the CML and subsequent exposure to surface solar irradiation increased bacterial activity compared to the dark control (Fig. 3). This photo-induced stimulation of bacterial activity was similar to that observed in the corresponding unamended treatments. However, BSA-amended, irradiated DW-DOM resulted in reduced bacterial activity compared to the respective dark control. This reduction in the bacterial activity on BSA-amended, irradiated DOM from deep waters has been described recently for Mediterranean mesopelagic waters also (Obernosterer et al. 1999b). Similarly, in a study on XAD-8-fractionated DOM from coastal marine sites, increased bacterial activity was observed in the nonhumic, BSA-amended, irradiated DOM fraction compared to the respective dark treatment, while decreased bacterial activity was observed in the humic, BSA-amended DOM fraction compared to the dark control (Obernosterer \& Herndl 2000). These results suggest that biologically labile DOM can be photochemically transformed, resulting in compounds that are biologically less available. BSA does not absorb in the wavelength range $>300 \mathrm{~nm}$. This further indicates that high molecular weight DOM, such as BSA, is, at least to a certain extent, transformed indirectly, via photosensitizers (Zepp et al. 1985). This is consistent with recent findings of Tranvik \& Kokalj (1998), who reported reduced bioavailability of irradiated algal-derived DOC in the presence of dissolved humic substances. In the present study, the higher DOM fluorescence of DW compared to that of the CML could indicate that the amount of precursors of photosensitizers is higher at depths $\geq 200 \mathrm{~m}$. This might explain the differential response of bacterial activity to BSAamended, irradiated DOM of varying depth layers. According to our results, the $<20 \mathrm{kDa}$ DOM fraction was mainly responsible for the photochemically induced stimulation of bacterial activity, while reduced bacterial activity was observed for irradiated BSA-amended DOM. This is consistent with the notion that the bioavailability of originally refractory low molecular weight DOM (Amon \& Benner 1994) increases upon exposure to surface solar irradiation, while bioreactive, largely high molecular weight DOM is rendered more refractory upon exposure to solar radiation.

In the present study, we presented further evidence of an inverse relationship between the initial biological reactivity of DOM and its bioavailability following exposure to surface solar radiation. Our results confirm the pattern previously described for the Gulf of Mexico (Benner \& Biddanda 1998) and the Mediterranean Sea (Obernosterer et al. 1999b), indicating that photochemical transformation can render labile DOM more refractory, while the bioavailability of originally recalcitrant DOM is increased upon irradiation. This suggests that the described relationship between the biological and the photochemical reactivity of DOM is also a common phenomenon in the Southern Ocean.

Acknowledgements. We thank M. Denis, the chief scientist of the 'Antares IV' cruise and the captain and the crew of the RV 'Marion Dufresne II' for their good cooperation and assistance and M. Fiala for providing chlorophyll a data. S. Gonzalez and C. Panagiotopoulos excellently performed the DOC analyses. This work is part of the French contribution to the JGOFS and has been supported by the PROOF (PROcessus biogeochimique Oceaniques et Flux) programme, the TAAF (Terres Australes et Antarctiques Françaises) department and the IFRTP (Institut Français pour la Recherche et la Technologie Polaires). Financial support was also provided by the fond of the French-Dutch scientific cooperation. This work is in partial fulfillment of the requirements for a $\mathrm{PhD}$ degree at the University of Groningen by I.O. This is publication no. 3549 of the NIOZ.

\section{LITERATURE CITED}

Amon RMW, Benner R (1994) Rapid cycling of high-molecularweight dissolved organic matter in the ocean. Nature 369:549-552

Anesio AM, Denward CMT, Tranvik LJ, Graneli W (1999) Decreased bacterial growth on vascular plant detritus due to photochemical modification. Aquat Microb Ecol 17: 159-165

Benner R, Biddanda B (1998) Photochemical transformations of surface and deep marine dissolved organic matter: effects on bacterial growth. Limnol Oceanogr 43:1373-1378

Benner R, Pakulski JD, McCarthy M, Hedges JI, Hatcher PG (1992) Bulk chemical characteristics of dissolved organic matter in the ocean. Science 255:1561-1564

Bertilsson S, Tranvik LJ (1998) Photochemically produced carboxylic acids as substrates for freshwater bacterioplankton. Limnol Oceanogr 43:885-895

Carlson CA, Ducklow HW (1995) Dissolved organic carbon in the upper ocean of the central equatorial Pacific Ocean, 1992: daily and finescale vertical variations. Deep-Sea Res II 42:639-656

Carlson DJ, Mayer LM, Brann ML, Mague TH (1985a) Binding of monomeric organic compounds to macromolecular dissolved organic matter in seawater. Mar Chem 16:141-153

Carlson DJ, Mayer LM, Brann ML, Mague TH (1985b) Molecular weight distribution of dissolved organic materials in 
seawater determined by ultrafiltration: a re-examination. Mar Chem 16:155-171

Cauwet G (1994) HTCO method for dissolved organic carbon analysis in seawater: influence of catalyst on blank estimation. Mar Chem 47:55-64

Cooper WJ, Zika RG, Petasne RG, Plane JM (1988) Photochemical formation of $\mathrm{H}_{2} \mathrm{O}_{2}$ in natural waters exposed to sunlight. Environ Sci Technol 22:1156-1160

Gobler CJ, Hutchins DA, Fisher NS, Cosper EM, SanudoWilhelmy S (1997) Release and bioavailability of C, N, P, $\mathrm{Se}$, and Fe following viral lysis of a marine chrysophyte. Limnol Oceanogr 42:1492-1504

Goldman JC, Caron DA, Dennett MR (1987) Regulation of gross growth efficiency and ammonium regeneration in bacteria by substrate C:N ratio. Limnol Oceanogr 32: $1239-1252$

Graneli W, Lindell M, Tranvik L (1996) Photo-oxidative production of dissolved inorganic carbon in lakes of different humic content. Limnol Oceanogr 41:698-706

Guo L, Santschi PH, Warnken KW (1995) Dynamics of dissolved organic carbon (DOC) in oceanic environments. Limnol Oceanogr 40:1392-1403

Harvey GR, Boran DA, Chesal LA, Tokar JM (1983) The structure of marine fulvic and humic acids. Mar Chem 12: 119-132

Keil RG, Kirchman DL (1994) Abiotic transformation of labile protein to refractory protein in sea water. Mar Chem 45:187-196

Kieber DJ, Daniel JM, Mopper K (1989) Photochemical source of biological substrates in sea water: implications for carbon cycling. Nature 341:637-639

Kieber RJ, Zhou X, Mopper K (1990) Formation of carbonyl compounds from UV-induced photodegradation of humic substances in natural waters: fate of riverine carbon in the sea. Limnol Oceanogr 35:1503-1515

Kieber RJ, Hydro LH, Seaton PJ (1997) Photooxidation of triglycerides and fatty acids in seawater: implication toward the formation of marine humic substances. Limnol Oceanogr 42:1454-1462

Kirchman DL, Lancelot C, Fasham M, Legendre L, Radach G, Scott M (1993) Dissolved organic matter in biogeochemical models of the ocean. In: Evans GT, Fasham MJR (eds) Towards a model of ocean biogeochemical processes. Springer-Verlag, Heidelberg, p 209-225

Kuipers B, van Noort GJ, Vosjan J, Herndl GJ (2000) Diel periodicity of bacterioplankton in the euphotic zone of the subtropical Atlantic Ocean. Mar Ecol Prog Ser 201:13-25

Lund V, Hongve D (1993) Ultraviolet irradiated water containing humic substances inhibits bacterial metabolism. Water Res 28:1111-1116

Miller WL, Zepp RG (1995) Photochemical production of dissolved inorganic carbon from terrestrial organic matter: significance to the oceanic organic carbon cycle. Geophys Res Lett 22:417-420

Mopper K, Zhou X, Kieber RJ, Kieber DJ, Sikorski RJ, Jones RD (1991) Photochemical degradation of dissolved organic carbon and its impact on the oceanic carbon cycle. Nature 353:60-62

Moran MA, Zepp RG (1997) Role of photoreactions in the formation of biologically labile compounds from dissolved organic matter. Limnol Oceanogr 42:1307-1316

Obernosterer I, Herndl GJ (2000) Differences in the optical and biological reactivity of the humic and non-humic DOC component in two contrasting coastal marine environments. Limnol Oceanogr 45:1120-1129

Obernosterer I, Kraay G, de Ranitz E, Herndl GJ (1999a) Concentrations of low molecular weight carboxylic acids and carbonyl compounds in the Aegean Sea (Eastern Mediterranean) and the turnover of pyruvate. Aquat Microb Ecol 20:147-156

Obernosterer I, Reitner B, Herndl GJ (1999b) Contrasting effects of solar radiation on dissolved organic matter and its bioavailabilty to marine bacterioplankton. Limnol Oceanogr 44:1645-1654

Orsi AH, Whitworth T III, Nowlin DN Jr (1995) On the meridional extent and fronts of the Antarctic Circumpolar Current. Deep-Sea Res I 42:641-673

Park YH, Gambéroni L, Charriaud E (1993) Frontal structure, water masses, and circulation in the Crozet Basin. J Geophys Res 98:12361-12385

Pausz C, Herndl GJ (1999) Role of ultraviolet radiation on phytoplankton extracellular release and its subsequent utilization by marine bacterioplankton. Aquat Microb Ecol 18:85-93

Reitner B, Herndl GJ, Herzig A (1997) Role of ultraviolet-B radiation on photochemical and microbial oxygen consumption in a humic-rich shallow lake. Limnol Oceanogr 42:950-960

Rich JH, Ducklow HW, Kirchman DL (1996) Concentrations and uptake of neutral monosaccharides along $140^{\circ} \mathrm{W}$ in the equatorial Pacific: contribution of glucose to heterotrophic bacterial activity and the DOM flux. Limnol Oceanogr 41:595-604

Rivkin RB, Anderson MR (1997) Inorganic nutrient limitation of oceanic bacterioplankton. Limnol Oceanogr 42:730-740

Salonen K, Vähätalo A (1994) Photochemical mineralisation of dissolved organic matter in Lake Skjervatjern. Environ Int 20:307-312

Skoog A, Biddanda B, Benner R (1999) Bacterial utilization of dissolved glucose in the upper water column of the Gulf of Mexico. Limnol Oceanogr 44:1625-1633

Suttle CA, Chan AM, Fuhrman JA (1991) Dissolved free amino acids in the Sargasso Sea: uptake and respiration rates, turnover times, and concentrations. Mar Ecol Prog Ser 70:189-199

Thingstad TF, Rassoulzadegan F (1995) Nutrient limitations, microbial food webs, and 'biological C-pumps': suggested interactions in a P-limited Mediterranean. Mar Ecol Prog Ser 117:299-306

Tranvik LJ (1990) Bacterioplankton growth on fractions of dissolved organic carbon of different molecular weights from humic and clear waters. Appl Environ Microbiol 56: 1672-1677

Tranvik LJ, Kokalj S (1998) Decreased biodegradability of algal DOC due to interactive effects of UV radiation and humic matter. Aquat Microb Ecol 14:301-307

Treguer P, Delmas R, Corre PL, Jehan SL, Masson A (1980) Cruise report ANTPROD II/MD 21. Univ. of Paris, Paris (Publication de l'institut Français pour la Recherche et la Technologie Polaires)

Whitworth T III, Worth DN Jr (1987) Water masses and currents of the Southern Ocean at the Greenwich Meridian. J Geophys Res 92:6462-6476

Wilkinson L (1990) SYSTAT: the system for statistics. SYSTAT, Inc, Evanston, IL

Yoro SC, Sempéré R, Turley C, Unanue MA, de Madron XD, Bianchi M (1997) Cross-slope variations of organic carbon and bacteria in the Gulf of Lions in relation to water dynamics (northwestern Mediterranean). Mar Ecol Prog Ser 161:255-264

Zepp RG, Schlotzhauer PF, Sink RM (1985) Photosensitized transformations involving electron energy transfer in natural waters: role of humic substances. Environ Sci Technol 19:74-81

Submitted: April 3, 2001; Accepted: December 15, 2000

Proofs received from author(s): February 28, 2001 